\title{
Energy Losses through Unharnessed Biomass in South- Eastern Region of Nigeria
}

\author{
Achebe, C.H., S.C. Nwigbo, E.C. Chinwuko \& M.O. Odhomi
}

\begin{abstract}
The problem of over-dependence on the non-renewable and fastdepleting fossil fuels is one the world of science needs not wink at any longer. In Nigeria, the level of dependence on these fossil fuels has created a great disparity in the sourcing, harnessing, exploration and exploitation of these natural endowments vis-à-vis other energy sources. The truth of the matter is that virtually all other sources of energy are neglected, untapped and unutilized/underutilized. This research work was necessitated by the burden to create awareness on the quantity of energy lost as occasioned by this insensitive attitude of the society to these other forms of energy and the possible implications to the environment and economy. It is the view of these writers that diversification of our energy consumption is a potent panacea to the usual power shortages and high cost of energy in Nigeria. The research findings show that about $20.52 \%$ of domestic energy requirements of South-eastern region of Nigeria could be met through proper harnessing of biomass (biodegradable materials) for the production of biogas.
\end{abstract}

\section{Introduction}

The overall economic development of a country largely depends on the availability and consumption of energy. The categories of energy resources available can be classified into two: renewable and nonrenewable. The non-renewable sources, also called fossil fuels are readily in use in Nigeria, and their energy deposits are continuously depleted by our withdrawals. However, the renewable sources of energy, which are being deposited every day, are not fully in use. Bio- 
energy which is an alternative and cheap source of the renewable energy and which can be made available to both the rural and urban areas of the country spells a viable option.

Bio-energy is energy stored in biomass. Biomass materials include wood, grasses and other herbage, grain and sugar crops, crop residues, animal manure, food processing waste, kelp from ocean farms, oil bearing plants and other materials. Biomass can be converted to energy through direct combustion, thermo-chemical conversion processes, bio-photolysis and biological conversion processes. Biological conversion processes may either be by fermentation or by anaerobic digestion. The anaerobic bioconversion of biomass produces a mixture of carbon (iv) oxide, traces of other gases, and methane called biogas.

Apart from the problem of non-renewable nature of fossil fuels, they are also not domestically available when compared to biomass, which is always readily available and just lying around waiting to be harnessed. Also, the technological feasibility of obtaining fossil fuels is very low and economically demanding. In addition to the problem of environmental pollution caused by fossil fuels, even the methane resulting from the anaerobic digestion of unharnessed biomass (e.g. cow dung) while composting escape to the atmosphere. This adds to the accumulative green house gases causing ozone layer depletion, but when burnt, it produces carbon (iv) oxide, which results in the abatement of climatic changes (Charles \& Sanders, 1986).

In today's energy conscious world, alternative forms of energy are becoming more and more important in deciding the future of the world's energy needs. Anaerobic digestion is the most efficient process of capturing energy from biomass. Unlike fossil fuels, biomass is a natural by-product that is not hidden under the ground. It has no question of existence, does not require extraction from its 
source but is regularly deposited on daily basis and is economical. The purpose of this work is to promote anaerobic digestion as an environmentally friendly method of waste reduction and energy recovery. It also aims at providing an alternative energy supply for domestic purposes (cooking) such that families can easily turn away from the traditional fire place and have a biogas plant installed to provide energy for cooking and even lighting. This provides a smokefree and ash-free kitchen meaning that women will no longer be prone to lung and throat infections and can look forward to a longer life expectancy. Waste will no longer be stored in the home but will be fed directly into the biogas plant along with toilet waste thus resulting to improvement in the standard of hygiene and sanitary conditions. Biogas is used to heat and light homes, to cook and even to fuel buses. It has been called swamp gas or sewer gas at different points in time (Onyi, P.N., 2004).

Anaerobic digestion can be described as a two-stage process accomplished by several types of bacteria, which flourish in absence of oxygen. In the first stage (acidification), acid-forming bacteria called acidogens break complex organic waste down into simpler fatty acids. In the second stage (methane production stage), methaneforming bacteria (methanogens) consume the acids produced by the acidogens, generating biogas as a metabolic by-product.

Anaerobic processes can be managed in a "digester" (an air tight vessel) or a covered lagoon (a pond used to store manure) for waste treatment. The primary benefits of anaerobic digestion are nutrient recycling, waste treatment and odour control. Biogas produced in anaerobic digesters consists of methane (50\%-80\%), carbon (iv) oxide (20\%-50\%) and traces levels of other gases such as hydrogen, carbon (ii) oxide, nitrogen and hydrogen sulphide. The relative percentage of these gases in biogas depends on the feed material and the 
management of the process. When burned 0.028cubic meters, (a cubic foot) of biogas yields about $2.52 \mathrm{kcal}$ (10 Btu) of heat energy per percentage of methane composition.

\section{Materials and Methods:}

This research work carried out on the South-eastern region of Nigeria was geared towards establishing a basis for encouraging the healthy attitude of exploiting the much available and cleaner alternative energy sources. The South-eastern region of Nigeria is a tropical rain forest belt which has a land mass of about Eighty-three thousand, one hundred and thirty-nine Square Kilometers $\left(83,139 \mathrm{Km}^{2}\right)$. The climatic conditions of the region include the dry and wet seasons. A part of the dry season is the harmattan period, which accounts for only about $8 \%$ of the entire year. The population of the region is about 22,092,000 (22.10 million). Table 1 below shows the temperature record of the region consisting of the day-time and night-time ranges for the year 2006 .

We modified this record by plotting the available record on a graph for easy appreciation and use in determining the suitability of this research to our location (i.e. the south-eastern region of Nigeria). The graph in fig. 1 below is adapted from the weather information on Nigeria by The Department of Meteorological Services, World Weather Information Service. The temperature ranges obtained was used to ascertain the viability of the biogas option in terms of optimum gas yield in the region given the prevalent climatic conditions. This is further discussed in the results shown in figure 1 below.

Much of the agricultural and biological wastes are good substrate for biogas production. Based on the availability and accessibility, coupled with the production levels of divers' wastes, we decided to undertake a study to determine the quantity of biomass from various biodegradable sources available in the south-east Nigeria. These included cow dung, poultry droppings, goat/sheep dung, crop and human wastes. Various consultations and collections were made to 
ascertain the population of the research objects and the average quantity of waste each produces. Also, the average quantity of refuse disposed by the sanitation authorities over a one-year period was equally obtained from available records. The information so gathered was employed in calculating the volume of methane gas (biogas) derivable from the various sources. The next phase of work was the conversion of the volume of the derivable methane gas to the equivalent quantity of energy. Through this means the total derivable quantity of energy was deduced. We had to proceed to obtain data on the domestic energy consumption rate of electric power from the Power Holdings Nigeria, the quantity of kerosene and liquefied natural gas (LNG) used by the population and the average wood consumption rate. These gave an estimate of the total energy requirement for domestic purposes in the region. The total derivable biogas energy as compared with the total energy requirements thus gave the percentage of the total energy requirements of the region which could be met by the biogas option, otherwise the quantity/percentage of energy lost as a result of unharnessed biomass energy available in the region.

The graph above reveals that methane production is at maximum at temperature of $35 \mathrm{C}$. This will be one of the factors to consider in determining the viability of the biogas option. It is however interesting to note that the temperature range in the region is quite favourable as it lies very close to this optimum condition throughout the year.

Deductions were made using the information in the above table to ascertain the quantity of methane gas derivable from the various biodegradable materials available in the region. The available data is as presented from table 2 below.

\section{Results:}

The results obtained from this research work are shown in figure 2 below. The graph in figure 2 below shows the volume of methane produced per day at varying temperatures in South-eastern Nigeria. This compares favourably with that of figure 2 above. The 
temperature of $30-32 \mathrm{C}$ is prevalent in the region through the greater part of the year except during the harmattan season, which due to the global climatic changes now lasts for a staggered $2-4$ weeks. At such periods the temperature comes as low as $22 \mathrm{C}$. This accounts for only about $8 \%$ of the total time through the year. Thus, the condition ensures optimum biogas yield through the year and such spells a good option as an alternative energy source.

The total domestic energy consumption in the region stands at $51.259 \times 10^{10} \mathrm{MJ}$ per annum as shown in table 3 . This includes all sources of energy currently in use. Fossil fuels however, provide the largest chunk of the energy requirements to the tune of about $29.208 \times 10^{10} \mathrm{MJ}$ per annum.

\section{Mathematical Model:}

Deriving a mathematical model for gas production from a given biomass, the following assumptions were made (Andrew, P.S., 1977);

(i) There is no littering of the environment and no overflow of the dump containers

(ii) Rate of change of waste is proportional to rate at which waste is dumped

$\mathrm{V}(\mathrm{t}) \quad=$ volume of waste residue in the dump at time, $\mathrm{t}$

$\operatorname{VAR}(\mathrm{t}) \quad=$ waste addition rate in $\mathrm{Kg} /$ day at time, $\mathrm{t}$

$\operatorname{VDR}(\mathrm{t})=$ waste decomposition rate at time, $\mathrm{t}$

$\mathrm{VCC}=$ waste chemical coefficient per day

Thus, waste product concentration equation will be given as;

$$
\begin{aligned}
& \mathrm{V}(\mathrm{t}+\mathrm{dt})=\mathrm{V}(\mathrm{t})+\mathrm{dt}[\operatorname{VAR}(\mathrm{t})-\operatorname{VDR}(\mathrm{t})] \\
& \operatorname{VDR}(\mathrm{t})=(\operatorname{VCC}) \mathrm{V}(\mathrm{t})
\end{aligned}
$$


Where VCC is an auxiliary constant which is same as Volatile Solid (VS) in table 4 above

We define the levels of variable product content to obtain gas use;

$$
\begin{aligned}
& \mathrm{Q}(\mathrm{t}) \quad \text { = gas content in the dump at time, } \mathrm{t} \\
& \mathrm{QRR}(\mathrm{t}) \quad \text { = gas in the dump replacement rate } \\
& \mathrm{QUR}(\mathrm{t}) \quad \text { = gas usage rate }
\end{aligned}
$$

Auxiliary constants;

$$
\begin{aligned}
& \text { Qmax = maximum gas content in the dump } \\
& \mathrm{Ct} \quad \text { = adjustable time for gas replacement or turbulence } \\
& \text { coefficient } \\
& \mathrm{Cd} \quad \text { = gas demand coefficient or gas requirement of every } \\
& \text { dump }
\end{aligned}
$$

Therefore, gas concentration equation becomes;

$\mathrm{Q}(\mathrm{t}+\mathrm{dt})=\mathrm{Q}(\mathrm{t})+\mathrm{dt}\{[1 / \mathrm{Ct}(\mathrm{Qmax}-\mathrm{Q}(\mathrm{t}))]-[(\mathrm{Cd}) \operatorname{VDR}(\mathrm{t})]\}$

Where;

$$
\begin{aligned}
& \mathrm{QRR}(\mathrm{t})=(1 / \mathrm{Ct})[\mathrm{Qmax}-\mathrm{Q}(\mathrm{t})] \\
& \mathrm{QUR}(\mathrm{t})=(\mathrm{Cd}) \operatorname{VDR}(\mathrm{t})
\end{aligned}
$$

Thus;

$\mathrm{Q}(\mathrm{t}+\mathrm{dt})=\mathrm{Q}(\mathrm{t})+\mathrm{dt}[\mathrm{QRR}(\mathrm{t})-\mathrm{QUR}(\mathrm{t})]$ 


\section{Conclusion:}

Our research findings show that about $20.52 \%$ of the total annual domestic energy requirements of the South-eastern region of Nigeria could be met through harnessing of readily available biomass resources. This unfortunately, is lost and the Methane gas and other associated gases evolve into the atmosphere with the attendant negative implications. These include ozone layer depletion and the unfavourable green house effect.

It is the view of these researchers that the region and indeed the Nation at large should explore and exploit other alternative renewable energy sources. This will reduce the current trend of over-dependence on the nonrenewable fossil fuels reserves. These reserves are fast depleting and the consequences, if not checked on time, would be of a grave sort.

\section{References:}

Aguilar, F.X., (2001). How to Install a Polyethylene Biogas Plant. U.K: Integrated bio-system network.

American Society of Agricultural Engineers (ASAE), (1998). ASAE Standards Handbook.

Andrew, P.S., (1977). Methodology for Large-scale Systems, New York: McGraw Hill Inc.

An, B.X. \& Rodriguez, L. et al (1997). Installation and Performance of Low Cost Polyethylene Tube Digesters on Small- scale Farms, World Animal Review, 88(1), Pp38-47.

Avalone, E.A., \& Baumeister, T., (1997): Marks Standard Handbook for Mechanical Engineers, 10th ed., Singapore: McGraw Hill Inc.

Biogas Generator Basic Principles: A Renewable Energy Kit, http://www.re-energy.cal

Biogas in India: A sustainable energy success story, http://www.eren.doe.gov/ 
Bishop, R.J., \& Smallman, R.E., (1999). Modern Physical Metallurgy and Material Engineering, 6th ed., Reed Educational and Professional Publishing Ltd.

Boyd, R., \& Morrison, R., (2000). Organic Chemistr (6th ed.), New Delhi: Prentice-Hall of India Private Ltd.

Central Bank of Nigeria, (1997). Annual Report and Statement of Accounts.

Charles, L., \& Sanders, (1986). Toxicological Aspects of Energy Production. New York: Battle memorial institute Macmillan.

Clark, J., \& Garcelon, J., (No date) Waste Digester Design; Student and Instructor Manual. http://www.wddndx.html/

Crowley, F.W., Law, F.M., \& Twort, A.C., (1986). Water Supply. (3rd ed.). Edward Arnold Publishers Ltd.

Dangoggo, S.M., \& Fernando, C.E.C., (1986). Investigation of Some Parameters Which Affect the Performance of Biogas Plants. Nigeria Journal of Solar Energy, 5, Pp142-148.

Energy and Anaerobic Digestion: Applications of Biogas, http://www.biogasworks.com/

Gornall, L., (2003). Testing Bio-digester Performance, lesliegornall@dial.pipex.com

Harris, P.L., "An introduction to Biogas," Faculty of Sciences, Adelaide University, Roseworthy Campus, Australia, http://paul.harris@adelaide.edu.au/, http://www.roseworthy.adelaide.edu.au/

Harris, P.L.: "Beginners Tour of Biogas; Safety Precautions", Faculty of Sciences, Adelaide University, Roseworthy campus, Australia. http://www.roseworthy.adelaide.edu.au/

Harris, P.L., "Designing A Small Anaerobic Digester", Faculty of Sciences, Adelaide University, Roseworthy Campus, Australia, http://www.roseworthy.adelaide.edu.au/

McCarty, (1983). Simplified Monod Kinetics of Methane Fermentation of Animal Waste. Agricultural waste, 5, Pp116.

Ministry of Agriculture and Natural Resources Awka Zonal Office, Anambra State, Nigeria. 
Morrill, W.T., (1963). The Ibo in Twentieth Century. Calabar: Comparative Studies in Society and History, 5, Pp.424-448.

National Population Commission, Awka branch Office, Anambra State, Nigeria.

Nzimiro, I., (1965). "A Study of Mobility among the Ibos of Southern Nigeria. International Journal of Comparative Sociology, 6, Pp117-130.

Onyi, P.N., (2004): Isolation of Anaerobic Bacteria Associated With The Production of Biogas from Abdominal Waste, City Publishers.

Power Engineering International (2001). Biomass Technology-Renewable Energy Report, 11(9), Pp3843.

Preston, T.R., \& Rodriguez, L. (1997). Bio-digester Installation Manual, Ho Chi Minh City: University of tropical agriculture and forestry, Pp14-15.

The New Encyclopedia Britannica: Micropaedia, 15th ed., (1992). Encyclopedia Britannica Inc., 12, P523.

The New Encyclopedia Britannica: Micropaedia, 15th ed., (1992). Encyclopedia Britannica Inc., 6, P76:3b.

The New Encyclopedia Britannica: Micropaedia, 15th ed., (1992). Encyclopedia Britannica Inc., 9, P586:2b.

The World Fact-book (CIA), (1998), "1996 in Vegetation and Land Use Changes in Nigeria", Federal Office of Statistics, Lagos, Nigeria

Westcott, R.W., (1963). Ibo Phases. Anthropological Linguistics, 5, Pp6-9.

World Weather Information Service Information, http://www.worldweather.org/cloud 
Achebe, C.H., S.C. Nwigbo, E.C. Chinwuko \& M.O. Odhomi

Fig.1: Temperature records in south-eastern Nigeria in 2006.
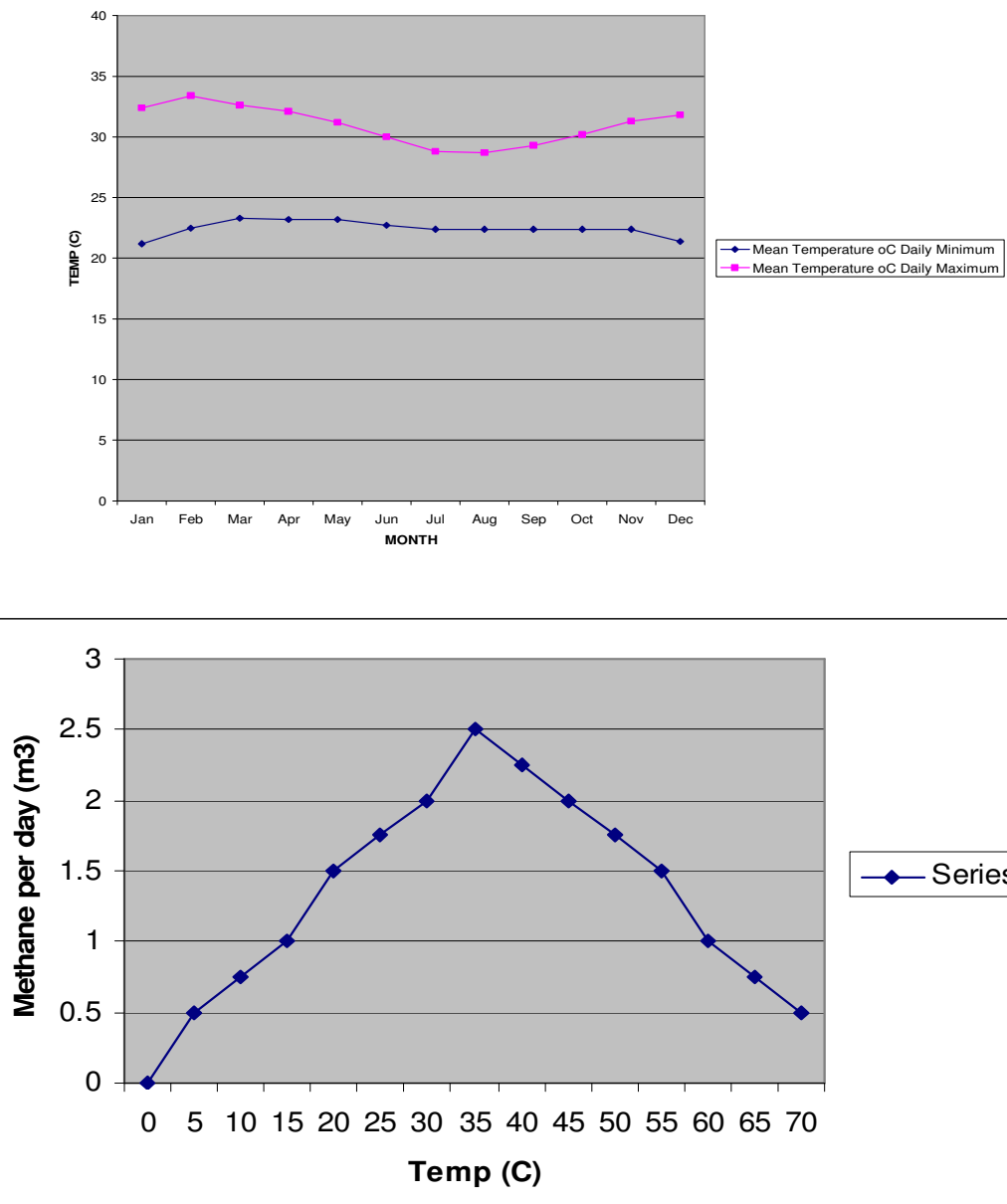

Fig. 2 Above: Methane production per day at varying temperatures in South-eastern Nigeria. 
Table1: Weather Information for South-eastern Nigeria (2006)

\begin{tabular}{|c|c|c|c|c|}
\hline \multirow[t]{2}{*}{ Month } & \multicolumn{2}{|c|}{ Mean Temperature $\left({ }^{0} \mathrm{C}\right)$} & \multirow{2}{*}{$\begin{array}{l}\text { Mean Total } \\
\text { Rainfall } \\
(\mathrm{mm})\end{array}$} & \multirow{2}{*}{$\begin{array}{l}\text { Mean Number } \\
\text { of Rain Days }\end{array}$} \\
\hline & $\begin{array}{l}\text { Daily } \\
\text { Minimum }\end{array}$ & $\begin{array}{l}\text { Daily } \\
\text { Maximum }\end{array}$ & & \\
\hline Jan & 21.2 & 32.4 & 22.2 & 2.2 \\
\hline Feb & 22.5 & 33.4 & 56.5 & 4.6 \\
\hline Mar & 23.3 & 32.6 & 116.3 & 8.6 \\
\hline Apr & 23.2 & 32.1 & 183.6 & 11.6 \\
\hline May & 23.2 & 31.2 & 222.7 & 14.2 \\
\hline June & 22.7 & 30.0 & 223.3 & 16.5 \\
\hline July & 22.4 & 28.8 & 356.5 & 19.7 \\
\hline Aug & 22.4 & 28.7 & 326.8 & 19.8 \\
\hline Sept & 22.4 & 29.3 & 367.1 & 20.1 \\
\hline Oct & 22.4 & 30.3 & 263.1 & 19.9 \\
\hline Nov & 22.4 & 31.3 & 96.9 & 5.9 \\
\hline Dec & 21.4 & 31.8 & 25.9 & 2.1 \\
\hline
\end{tabular}

(Source: World Weather Information Service, 2006) 
Achebe, C.H., S.C. Nwigbo, E.C. Chinwuko \& M.O. Odhomi

Table2: Biogas production from some common wastes.

\begin{tabular}{|l|l|l|}
\hline & Type of Waste & Gas Production $\left(\mathrm{Dm}^{3} / \mathrm{Kg}\right)$ \\
\hline 1. & Cattle dung & $22-40$ \\
\hline 2. & Pig dung & $40-60$ \\
\hline 3. & Poultry dropping & $65-115$ \\
\hline 4. & $\begin{array}{l}\text { Human (per person using } \\
\text { toilet) }\end{array}$ & $20-22$ \\
\hline 5. & Pre-treated crop waste & $34-40$ \\
\hline 6. & Water Hyacinth & $40-50$ \\
\hline
\end{tabular}

(Source: Fernando and Dangoggo, 1986)

Table3: Domestic Energy consumption in South-eastern Nigeria.

\begin{tabular}{|l|l|l|}
\hline Energy source & $\begin{array}{l}\text { Quantity of fuel } \\
(\mathrm{kg})\end{array}$ & $\begin{array}{l}\text { Energy requirement } \\
\text { per annum (MJ) }\end{array}$ \\
\hline Electricity & - & $25.790 \times 10^{9}$ \\
\hline Kerosene & $5,647,180,170$ & $24.340 \times 10^{10}$ \\
\hline LNG & $1,129,436,034$ & $48.680 \times 10^{9}$ \\
\hline Wood/Wood Wastes & $4,517,744,136$ & $19.472 \times 10^{10}$ \\
\hline Total & & $51.259 \times 10^{10}$ \\
\hline
\end{tabular}

Note: Kerosene heating value (heat of combustion) is $43.1 \mathrm{MJ} / \mathrm{Kg}$ (18500Btu/Ib) 
Energy Losses through Unharnessed Biomass in South-Eastern Region of Nigeria

Table 4: Quantity of Metha Available and \% Energy Losses

\begin{tabular}{|c|c|c|c|c|c|c|c|c|}
\hline $\begin{array}{l}\text { Biomass } \\
\text { Source }\end{array}$ & $\begin{array}{l}\text { Average } \\
\text { mass of } \\
\text { waste per } \\
\text { item per day } \\
(\mathrm{Kg})\end{array}$ & $\begin{array}{l}\text { Populati- } \\
\text { on of } \\
\text { item per } \\
\text { day }\end{array}$ & $\begin{array}{l}\text { Mass of waste } \\
\text { per annum }(\mathrm{Kg})\end{array}$ & $\begin{array}{l}\text { Volatile } \\
\text { Solid } \\
\text { (VS) per } \\
\mathrm{Kg} \\
\text { waste }\end{array}$ & $\begin{array}{l}\text { Gas } \\
\text { production } \\
\left(\mathrm{m}^{3} / \mathrm{Kg}\right)\end{array}$ & $\begin{array}{l}\text { Quantity of gas } \\
\left(\mathrm{m}^{3}\right)\end{array}$ & Energy value (MJ) & $\begin{array}{l}\% \text { of total } \\
\text { energy } \\
\text { require- } \\
\text { ment }\end{array}$ \\
\hline Cattle dung & 3.60 & 25,000 & $32,895,000$ & 0.12 & 0.040 & 157,896 & $6,157,944$ & 0.0012 \\
\hline $\begin{array}{l}\text { Human } \\
\text { waste }\end{array}$ & 0.60 & $\begin{array}{l}22,092,0 \\
00\end{array}$ & $4,844,775,600$ & 0.03 & 0.022 & $3,197,551.90$ & $124,704,523.94$ & 0.0243 \\
\hline $\begin{array}{l}\text { Poultry } \\
\text { droppings }\end{array}$ & $1.24 \times 10^{-3}$ & 300,000 & 135,966 & 0.19 & 0.115 & $2,970.86$ & $115,863.43$ & 0.00002 \\
\hline $\begin{array}{l}\text { Goat/Sheep } \\
\text { dung }\end{array}$ & 0.40 & 150,000 & $21,930,000$ & 0.23 & 0.040 & 201,756 & $7,868,484$ & 0.0015 \\
\hline Pig dung & 0.50 & 10,000 & $1,827,500$ & 0.10 & 0.060 & 10,965 & 427,635 & 0.00008 \\
\hline $\begin{array}{l}\text { Refuse (bio- } \\
\text { degradable) }\end{array}$ & $1,000,000$ & - & $365,500,000$ & 0.30 & 0.064 & $7,017,600$ & $273,686,400$ & 0.0534 \\
\hline Crop waste & $600,000,000$ & - & $219,300,000,000$ & 0.30 & 0.040 & $2,631,600,000$ & $102,632,400,000$ & 20.022 \\
\hline $\begin{array}{l}\text { Water } \\
\text { Hyacinth }\end{array}$ & $10,000,000$ & - & $3,655,000,000$ & 0.30 & 0.050 & $54,825,000$ & $2,138,175,000$ & 0.4171 \\
\hline Total & - & - & $228,222,064,066$ & - & - & $2,697,013,739.76$ & $105,183,535,850.37$ & 20.52 \\
\hline
\end{tabular}

Note: $1.00 \mathrm{~m}^{3}$ of methane gas yields 39MJ of energy (An, B.X. and Rodriguez, L.1997). 